\title{
Early use of marine resources by Middle/Upper Pleistocene human societies: The case of Benzú rockshelter (northern Africa)
}

\author{
José Ramos-Muñoz ${ }^{\text {a, * }}$, Juan Jesús Cantillo-Duarte ${ }^{a}$, Darío Bernal-Casasola ${ }^{a}$, \\ Antonio Barrena-Tocino a , Salvador Domínguez-Bella ${ }^{b}$, Eduardo Vijande-Vila ${ }^{a}$, \\ Ignacio Clemente-Conte ${ }^{\text {c }}$, Igor Gutiérrez-Zugasti ${ }^{\mathrm{d}}$, Mila Soriguer-Escofet ${ }^{\mathrm{e}}$, \\ Sergio Almisas-Cruz ${ }^{\text {a }}$ \\ a Departamento de Historia, Geografía y Filosofía, Facultad de Filosofía y Letras, Universidad de Cádiz, Avenida Gómez Ulla s.n, 11003 Cádiz, Spain \\ b Departamento de Ciencias de la Tierra, Facultad de Ciencias, Universidad de Cádiz, Campus Río San Pedro, Puerto Real, 11510 Cádiz, Spain

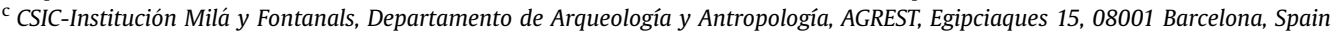 \\ d Instituto Internacional de Investigaciones Prehistóricas de Cantabria, Universidad de Cantabria, Avda. de los Castros, s/n, 39005 Santander. Spain \\ e Departamento de Biología Animal, Facultad de Ciencias del Mar, Universidad de Cádiz, Campus Río San Pedro, Puerto Real, 11510 Cádiz, Spain
}

\section{A R T I C L E I N F O}

\section{Article history:}

Available online 26 March 2016

\section{Keywords:}

Benzú

Historical region

Straits of Gibraltar

Pleistocene

Marine resources

\begin{abstract}
A B S T R A C T
This article examines the role played by marine resources for hunter-gatherer groups of the Middle/ Upper Pleistocene in the geohistorical region around the Straits of Gibraltar, on the basis of new evidence collected at the rock shelter of Benzú (North Africa). The stratigraphic sequence at Benzú has been dated to between 254 and $70 \mathrm{ka}$. The excavations have revealed the exploitation of marine gastropods and bivalves, alongside fish. The most common taxon in the sequence is the genus Patella. The analysis of the molluscs and their spatial distribution shows that these animals were purposely collected by humans, probably as a food source. In order to contribute to the debate about the origins and scale of the exploitation of marine resources during the Middle and Upper Pleistocene, the evidence collected at Benzú is interpreted within the broader context of North Africa and southern Europe. The similarity of groups of Homo sapiens sapiens in North Africa and Homo sapiens neanderthalensis in southern Europe in terms of lifestyle and subsistence strategies is interpreted as reflecting equally similar social and economic practices, in spite of the diversity of anthropological perspectives on the relationship between humans and the environment currently in vogue.
\end{abstract}

(c) 2016 Elsevier Ltd and INQUA. All rights reserved.

\section{Hunter-gatherer societies and the exploitation of marine resources}

Recent interdisciplinary research carried out in various parts of the world, for example southern Africa (Marean et al., 2007) and the Mediterranean basin (Vanhaeren et al., 2006; Colonese et al., 2011), is changing our perspective on hunter-gatherer societies in the Middle and Late Pleistocene, by demonstrating the important role played by shellfishing and the exploitation of other marine resources (Flemming et al., 2003). These practices have been attested on both shores of the Strait of Gibraltar (Finlayson, 2008,

\footnotetext{
* Corresponding author

E-mail address: jose.ramos@uca.es (J. Ramos-Muñoz).
}

2009; Stringer et al., 2008; Brown et al., 2011; Cortés et al., 2011; Ramos et al., 2011a,b; 2014b).

Recent advances in the field of anthropology and archaeology have posed a solid challenge to models primarily based on hunting - the 'Man the Hunter' hypothesis (Lee and De Vore, 1968). According to this hypothesis, hunting was the main economic practice in high latitudes, whereas fishing was predominant in mild latitudes (Lee, 1968: 42).

Nonetheless, a large proportion of anthropological and archaeological theories have insisted on regarding Middle and Upper Pleistocene human groups simply as hunter-gatherer societies. This idea is now being challenged by the recent stress on multidisciplinary studies that go beyond regional modelling, including, among others, kinship analysis, social studies, taphonomic analysis, resource analysis, gender studies, labour-division studies, the introduction of new perspectives to the analysis of artistic 
manifestations, territorial analysis and mobility analysis (Bate, 1982; Dennell, 1987: 30-31; Ingold et al., 1988; Otte, 1996; Gamble, 1999; Ramos, 1999).

In this regard, getting over the evolutionist perspective of 'needs' and 'limits' (Shalins, 1977) has been an important step for the recognition of the importance of vegetable and marine resources in the subsistence of human groups in the Middle and Upper Pleistocene. From our point of view, the role played by these resources goes even beyond the limited perspective offered by the 'broad spectrum economy' model (Stiner et al., 1999, 2000; Stiner, 2001). A varied diet is consubstantial to our species, "the evidence seems to suggest that a swing between economies based on one animal species and economies based on a wide range of resources took place in Europe in the Late Pleistocene" (Estévez et al., 1998: 17). Based on this idea, is therefore important to define which groups made marine resources a key factor in their subsistence in mild latitudes. Our analysis will not go into biotechnological questions regarding the relationship between technology and culture, but this is a recurrent issue in discussions concerned with the connection between biological change, essentially, the transition between Neanderthals and modern humans (Mellars, 1999; Zilhao, 2008), and the geographical expansion of economic practices (Martin and Klein, 1984; Klein, 2008).

In recent years, considerable progress has been made with regard to the association of several human groups and marineresource exploitation practices. Specifically, in Atlantic and Mediterranean southern Europe, these economic strategies are being linked with groups of Neanderthals (Finlayson et al., 2006; Finlayson, 2008, 2009; Stringer et al., 2008; Zilhao et al., 2010; Colonese et al., 2011; Cortés et al., 2011), whereas in Africa these practices seem to be associated with Homo sapiens sapiens (Marean et al., 2007; McBrearty and Stringer, 2007; Jacobs et al., 2008; Collina-Girard and Bouzouggar, 2013). The evidence, therefore, suggests that marine resources played an important role in the subsistence of these groups, which may rightly be defined as hunter-gatherer-fishers.

The extraction of marine resources is also linked to the emergence of elements of personal adornment, ochre and 'artistic' behaviour; this is a widely debated issue in relation to the earliest instances of symbolic thought (D'Errico et al., 2005), a field where recent research has also made considerable progress. It is now thought that African artistic manifestations are at least 35,000 years earlier (D'Errico et al., 2005, 2009) than those in Grotte Chauvet (Clottes, 2001; Geneste, 2005), one of the most outstanding examples of Palaeolithic art in southern Europe.

\section{A global perspective on the evidence: the contrast between the European Mediterranean and the near eastern, North African and South African records}

Growing interest in the reconstruction of prehistoric coastlines and the impact of glacioeustatic factors has allowed a more realistic perspective on coastal Pleistocene environments in different parts of the world. For example, multidisciplinary studies are currently evaluating the plausibility of land-bridges in connection with human dispersion (Otte, 2013). These new perspectives are opening avenues for the analysis of the relationship between human expansion and mobility and coastal environments during the Pleistocene (Flemming et al., 2003). For instance, the scientific interest of submerged coastal platforms has now been recognised. During cold periods in the Pleistocene, these platforms offered wide territories and ample resources to the inhabitants of caves and other sites located near the modern shoreline (Flemming et al., 2003; Rodríguez Vidal et al., 2004; Rodríguez Vidal and Cáceres, 2005; Chamorro et al., 2011).

In connection with this, the important role played by molluscs, and the marine resources in general, in the survival of huntergatherer groups, is being increasingly acknowledged (Erlandson, 2001; Finlayson et al., 2006; Marean et al., 2007; Bailey and Flemming, 2008; Fa, 2008; Colonese et al., 2011). We shall present evidence (Fig. 1) in support of the association of preNeanderthal and Neanderthal groups and these resources in southern Europe, and we shall then compare this data with that pertaining to groups of modern humans in Africa and the Middle East.

The earliest evidence in this regard, which was dated to $c .300 \mathrm{ka}$ (Mode II- Acheulian), was found in the cave of Terra Amata (Nice, France) (De Lumley, 1966). This evidence relates to pre-Neanderthal

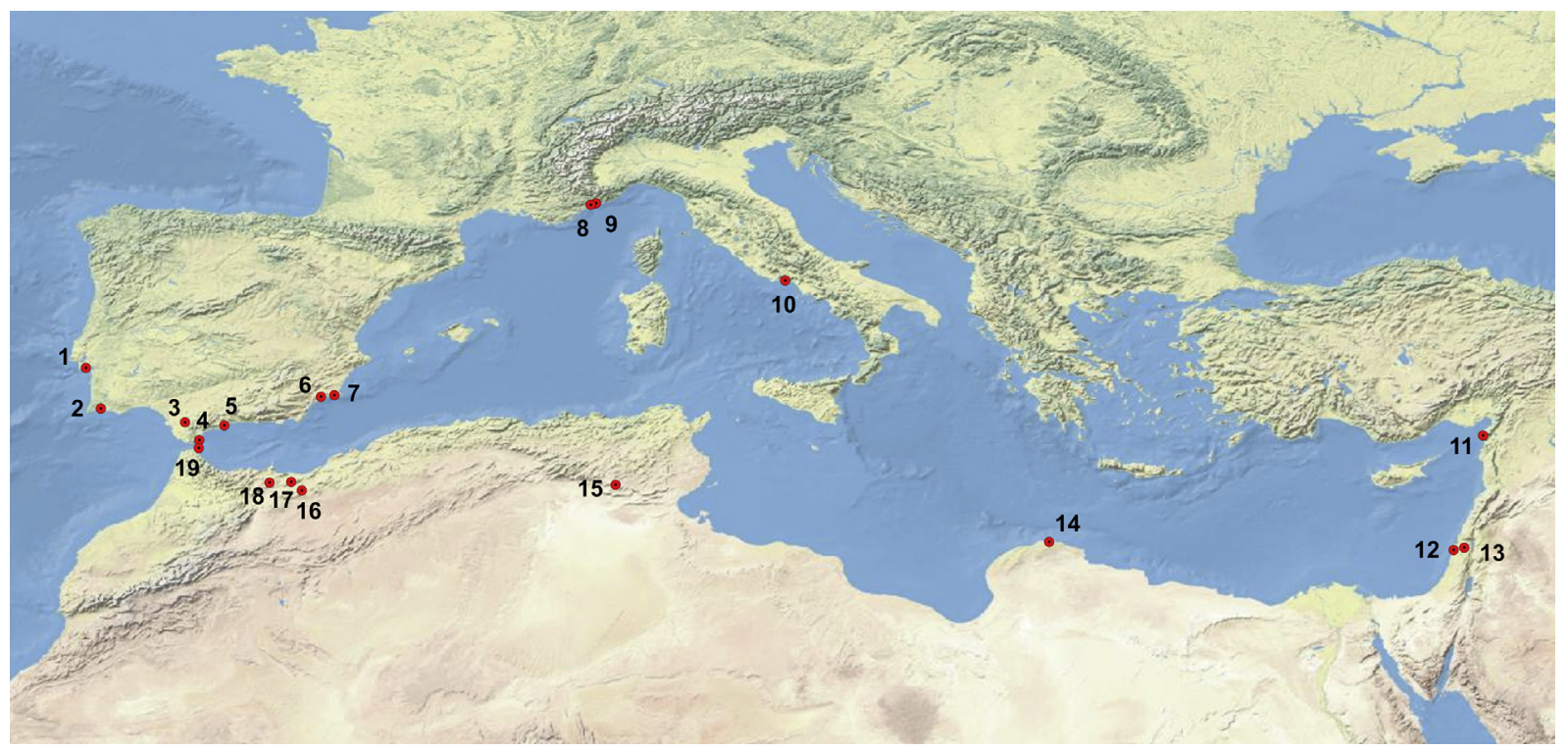

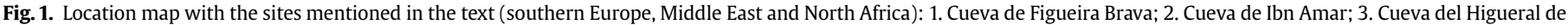

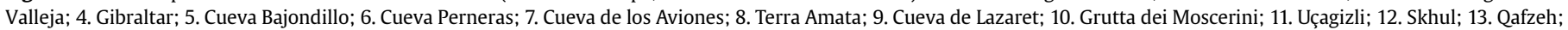
14. Haua Fteah; 15.Oued Djebbana; 16.Rhafas; 17. Taforalt; 18. Ifri n’Amar; 19. Benzú. 
groups, and the associated molluscs include Ostreidae, Mytilidae and Patellidae. The molluscs identified in the Cave of Lazaret (Nice, France), also related to Mode II-Acheulian technology and dated to MIS 6 (186-127 ka), included Patellidae, Trochidae and Littorinidae (Barrière, 1969).

Regarding the Iberian Mediterranean coast, our evidence for the relationship between the exploitation of marine resources and Neanderthal groups has increased substantially in recent years (Zilhão, 2001; Stringer et al., 2008; Finlayson, 2009; Zilhão et al., 2010). On the Portuguese Atlantic coast, an interesting animal assemblage has been attested at Grota da Figueira Brava (Sesimbra), near Setubal, south of Lisbon. This assemblage, found in association with Mode III-Mousterian technology, has been dated to c. $60 \mathrm{ka}$ (Zilhão, 2012). The assemblage includes an interesting combination of sea and land species. Among the former, molluscs take a prominent position (especially Patella vulgata) but the presence of Pusa hispida, Pinguinus impennis and Delphinus delphis is also significant. It is believed that the presence of these species responds to scavenging activities practiced on beached animals (Tavares y Soares, 1998; Callapez, 2000; Zilhão, 2001, 2012).

Evidence for the exploitation of marine species has also been attested at other sites, such as Furninha (Peniche) (Bicho and Cardoso, 2010). Recent research has also increased our knowledge of the exploitation of marine resources in the Algarve. Evidence collected at the cave of Ibn Amar (Lagoa) and its hinterland has revealed the exploitation of small land species and of aquatic taxa in association with Mode III-Mousterian technology. The molluscs documented include Mytilus and Cerastoderma, which implies the proximity of the coastline (Bicho, 2001: 529). In this regard, Joao Zilhao has proposed a territorial model based on the exploitation of resources found in the immediate vicinity of habitation sites. Coastal locations were thus exploited within the regular mobility pattern of human groups, which also included inland settlements (Zilhão, 2001: 606).

Some interesting evidence has been compiled in the southernmost coast of the Iberian Peninsula, the Strait of Gibraltar (Fig. 1) and the Bay of Malaga, including the sites of Gibraltar (Finlayson, 2008, 2009) and Bajondillo (Cortés, 2007). In the southeast Iberian Peninsula, marine molluscs have been attested in association with Mode III-Mousterian technology at Cueva Perneras and Cueva de los Aviones (Montes, 1989). At both sites, species that inhabit rocky coastlines, such as Phorcus turbinatus, Patella sp and Mytilus galloprovincialis are clearly predominant, and amount to $98 \%$ of the total number of specimens. At Cueva de los Aviones, the animal remains are associated with a Neanderthal group and are dated to $50 \mathrm{ka}$. The shells could have been used for personal decoration, and some may preserve the remains of pigments ( $G$. insubrica and $S$. gaederopus); some of these shells may have also been used as containers for body paints (Zilhão et al., 2010).

Regarding similar Central Mediterranean examples found in association with Mode III-Mousterian technologies, we must mention Grotta dei Moscerini (Lazio, Italy) dated to between 115 and $110 \mathrm{ka}$ and $65 \mathrm{ka}$. Shells corresponding to infralittoral taxa (C. chione y Glycymeris sp.) are documented in all levels along with the remains of other marine species, for example $M$. monachus (Stiner, 1994). Some of these shells were used for tool manufacture (Vitagliano, 1984; Stiner, 1994).

In Africa and the Middle East, these remains are found in association with groups of Homo sapiens sapiens. The evidence for the eastern Mediterranean is still scant. We must now mention the classic sites of Skhul Cave and Qafzeh Cave (Israel), where marine shells were found in relation to groups of anatomically modern humans (Bar-Yosef Mayer, 2005; Vanhaeren et al., 2006). Good evidence for the exploitation of marine resources and molluscs has also been collected in the cave of Uçagizli (Turkey), dated to the
Early Upper Palaeolithic and the cave of Ksar'Akil (Lebanon) (Kuhn et al., 2001).

Concerning North Africa, one of the most interesting sequences is found at Haua Fteah (Cyrenaica, Libya), with a starting date around $100 \mathrm{ka}$ (McBurney, 1967). Molluscs are present in the levels associated with Mousterian and Dabban (Upper Palaeolithic) industries (Hiscock, 1996). The species found at this site include P. caerulea and Phorcus turbinatus. The exploitation of these marine resources is related to groups of Homo sapiens sapiens (Barker et al., 2009). In Oued Djebbana (Algeria), perforated examples of Nassarius gibbosulus, dated to around $100 \mathrm{ka}$ (Vanhaeren et al., 2006), have been attested; this species is valueless in nutritional terms, and was therefore exploited for symbolic reasons.

Another example of the use of perforated Nassarius gibbosulus shells for personal adornment in North Africa is the cave of Pigeons (Taforalt, Morocco), which is located approximately $40 \mathrm{~km}$ from the coast. The perforated shells were found in Aterian (Middle Palaeolithic) and Ibero-Mauritanian (Upper Palaeolithic) lithic technologies. The Group E-Aterian assemblage, which was dated to $82.5 \mathrm{ka}$, includes 13 beads crafted out of Nassarius gibbosulus shells (Bouzouggar et al., 2007: 9966). More evidence from this context was published latter (D'Errico et al., 2009: 16052). These shells were not gathered for consumption, and were involved in redistribution processes between the coast and the interior. Some of the beads preserve microscopic remains of red pigment.

Similar perforated shells have also been found at the cave of Ifri n'Amar (Plaine de Guerouaou, Eastern Rif, Morocco), 59 km from the Mediterranean coast. These examples of Nassarius (Nami and Moser, 2010: 41) were found in association with Middle Palaeolithic Aterian technology and remains of red ochre. The chronology of this sequence is surprisingly old (Mikdad et al., 2004; Eiwanger, 2004; D'Errico et al., 2009: 16053; Nami and Moser, 2010: 264). A last example is Grotte Rhafas (Eastern Morocco), located $50 \mathrm{~km}$ from the Mediterranean coast, where the perforated shells are also associated with Aterian industries; the chronology for this assemblage is 80-60 ka (Wengler, 2001; D'Errico et al., 2009: 16053).

As previously noted, these inland North African sites are associated with Aterian technologies. The perforated and pigmented shells must have been part of distribution mechanisms connecting the coast and the interior, a phenomenon that has also been attested in South Africa. These evidences are an important contribution to the current debates about the progressive or sudden emergence of practices of personal decoration, which are taken to be a reflection of symbolic behaviour (D'Errico et al., 2009).

In South Africa, the earliest evidence for the exploitation of marine resources is dated to $164 \mathrm{ka}$ at Pinacle Point, a site related to groups of Homo sapiens sapiens (Marean et al., 2007). The site, which is important for the construction of the sequence of human expansion along the southern and eastern African coast, has been associated with the cold and dry MIS 6 period. Evidence for the use of pigments has been attested. The assemblage of marine invertebrates is of enormous interest, especially Perna perna, Choromytilus meridionales and Scutellastra argenvillei. Most molluscs (Jerardino and Marean, 2010, 2014) were gathered in rocky environments and tide pools. From an adaptationist perspective, the exploitation of marine resources has been interpreted as a response to the lower productivity of land environments during cold periods (Marean et al., 2007: 906). Other South African coastal sites with evidence for the exploitation of marine resources are Blombos Cave and Klasies River (Jacobs et al., 2008).

Blombos has been dated to around $77 \mathrm{ka}$, and yielded very wellknown fragments of ochre decorated with geometric motifs and shell beads, which have been interpreted as evidence for symbolic behaviour associated with modern humans (Henshilwood et al., 
2001, 2002; McBrearty and Stringer, 2007). A recent publication has mentioned the discovery at Blombos of two shells of Haliotis midae used for the manufacture of pigments. These shells were found in association with lithic instruments, which were employed to grind the ochre mineral, mammal bones and charcoal and stone fragments, which were contained within the shells (Henshilwood et al., 2011). All this is in addition to the site's interesting bone tool assemblage and the lithic tools typical of Middle Stone Age industries (Mourre et al., 2010). This South African evidence, therefore, is associated with Middle Stone Age industries and the beginnings of symbolic thought (McBrearty and Stringer, 2007; Jacobs et al., 2008) and demonstrate these groups' ability to gather different raw materials, mix them and use them in the course of social practices (Henshilwood et al., 2011).

\section{The geohistorical region of the Strait of Gibraltar}

The evidence suggests that, in the geo-historical region of the Strait of Gibraltar, fishing and shellfishing were important subsistence strategies (Vanney and Menanteau, 2004; Finlayson et al., 2006; Cortés, 2007; Stringer et al., 2008; Ramos and Cantillo, 2009; Cantillo et al., 2010; Ramos et al., 2011a,b; Ramos et al., 2014 b).

The analysis of Quaternary sea level changes in the region has yielded interesting results in recent years. Changes in sea levels are related to climatic changes (Zazo et al., 1997: 25). These analyses have been carried out on the coast of Malaga (Cortés and Simón, 2000; Rodríguez Vidal et al., 2007; Cortés, ed., 2007), the region around the Strait (Domínguez-Bella et al., 1995; Ramos et al., 2002; Gracia, 2008; Torres, 2008), Gibraltar (Fa et al., 2000; Rodríguez Vidal and Gracia, 2000; Abad et al., 2007, 2013) and the Atlantic coast of Cádiz (Menanteau et al., 1983; Zazo et al., 1999; Gracia, 1999, 2008). Sea level shifts have thus been documented at beaches and cliffs in the region, which is highly relevant for the use of marine resources, because it has contributed to a broader variety of species in both sandy and rocky environments (Gracia, 1999).

It seems clear that human occupation has been intimately connected with eustatic oscillations and their impact on the availability of marine resources. Coastal human settlements, associated with Mode II technologies, have been attested in the Bay of Málaga (Ramos Fernández et al., 2011-2012), the Atlantic coast of Cádiz (Ramos, 2008), and the region around the Strait of Gibraltar (Castañeda, 2008). At any rate, there is no evidence for the exploitation of marine resources by pre-Neanderthal groups in the region, which can only be associated with human groups characterised by Mode III technological assemblages (Finlayson et al., 2006; Stringer et al., 2008; Cantillo et al., 2010; Ramos et al., 2011a,b). The similarity of the record in Benzú (North Africa, near Ceuta), Cueva de Bajondillo (Bay of Malaga) (Rodríguez Vidal et al., 2007; Cortés, ed., 2007; Cortés, 2007), and Gibraltar (Stringer et al., 2008; Finlayson, 2009) illustrate a similar lifestyle and technological baggage (Mode III) on both shores of the Strait of Gibraltar.

\section{North Africa: the rock shelter of Benzú}

The rock shelter of Benzú is located in Ceuta, in the North African shore of the Straits of Gibraltar (Ramos et al., 2008, 2014 a; 2014 b; Ramos et al., 2011a,b; Ramos et al., 2013). The rock shelter is located at a distance of $230 \mathrm{~m}$ from the current shore line. Sedimentation studies have identified 10 stratigraphic levels (numbered from the base upwards). Levels 1-7 contain evidences of human occupation with lithic artefacts bone and shell, and a maximum depth of $\mathrm{w}$ 5.5. m. Benzu rockshelter is situated at 63 m.a.s.l. (Fig. 2), close to the stream of Algarrobo and the Bay of Ballenera, within a predominantly coastal environment. During

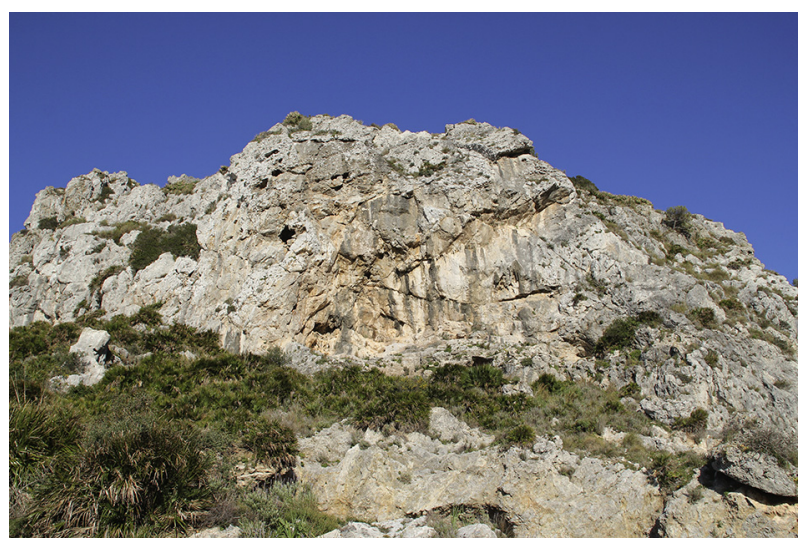

Fig. 2. Rock shelter of Benzú.

cold Quaternary phases, the sea level retreated as much as $120 \mathrm{~m}$, which created an ample platform, currently submerged, from which the occupants of Benzú must have extracted a wide variety of resources.

A team from University of Cádiz, under the direction of José Ramos and Darío Bernal, has carried out six excavation seasons at the site. Excavation has revealed a stratigraphic sequence of ten strata (Fig. 3), seven of which contain evidence for human occupation during the Middle and Upper Pleistocene. Dates are available for strata 10 (Th/U, IGM: $\pm 70 \mathrm{ka}$ ), 7 (TL, Mad-3177: $74.9 \pm 7.5 \mathrm{ka}), 5$ (OSL, Shfd 020136: $168 \pm 11 \mathrm{ka}$ ), 3b (Th/U, IGM: $173 \pm 10 \mathrm{ka}$ ), and 2 (OSL, Shfd 020135: $254 \pm 17 \mathrm{ka}$ ). Micromorphology and bioerosion studies have confirmed that the formation of the rock shelter must be dated to MIS 9, and is therefore earlier than the first episode of human occupation (Abad et al., 2007).

The stratigraphic deposits are mostly composed of cemented calcite, and an unusual excavation methodology has had to be applied. First, blocks of soil $(25 \times 25 \times 15 \mathrm{~cm})$ were extracted with wedges. Afterwards, these blocks were excavated in the laboratory with compressed air micro-drills, and the location of the archaeological finds within precisely recorded (Domínguez-Bella et al., 2012). Animal remains were consolidated with Paraloid $\mathrm{B}^{72}$ dissolved in acetone (at $5 \%, 10 \%$ and even $30 \%$, according to the specific hardness of the breccia) prior to extraction. In some cases, xylene was used instead of acetone, due to its higher degree of penetration into the molluscs' calcium carbonate. Hammers and chisels were also used in the excavation process.

Pollen analyses have yielded a homogeneous composition throughout the sequence. Regionally, the most significant taxon is Cedrus and, to a lesser extent, Pinus. Locally, vegetation was dominated by Quercus-p (holm oak), Olea, carob trees and riverside taxa, for example Alnus, Salix and Ulmus. Grasses are dominated by steppe-species (Artemisia, Asteraceae and Chenopodiaceae). Bushes, among which Ericaceae and Juniperus were the most common species, did not play a significant role in the plant environment. The prevalent Mediterranean environmental conditions were generally dry, but the presence of more or less permanent water courses and water pools favoured the development of riverside and water taxa. The sequence attests to environmental oscillations and shifts within a general trend towards progressively drier conditions over time. The cyclical variations resulted in the expansion of woods inhabited by Mediterranean and temperate species, a varied population of grasses and bushes and a high presence of riverside and water taxa (Ruiz Zapata and Gil, 2013). The analysis of the oxygen and carbon isotopes present in mollusc shells, currently under way, is expected to reveal more details about the climatic and environmental conditions in the Strait of Gibraltar during the periods of occupation of the rock shelter. 

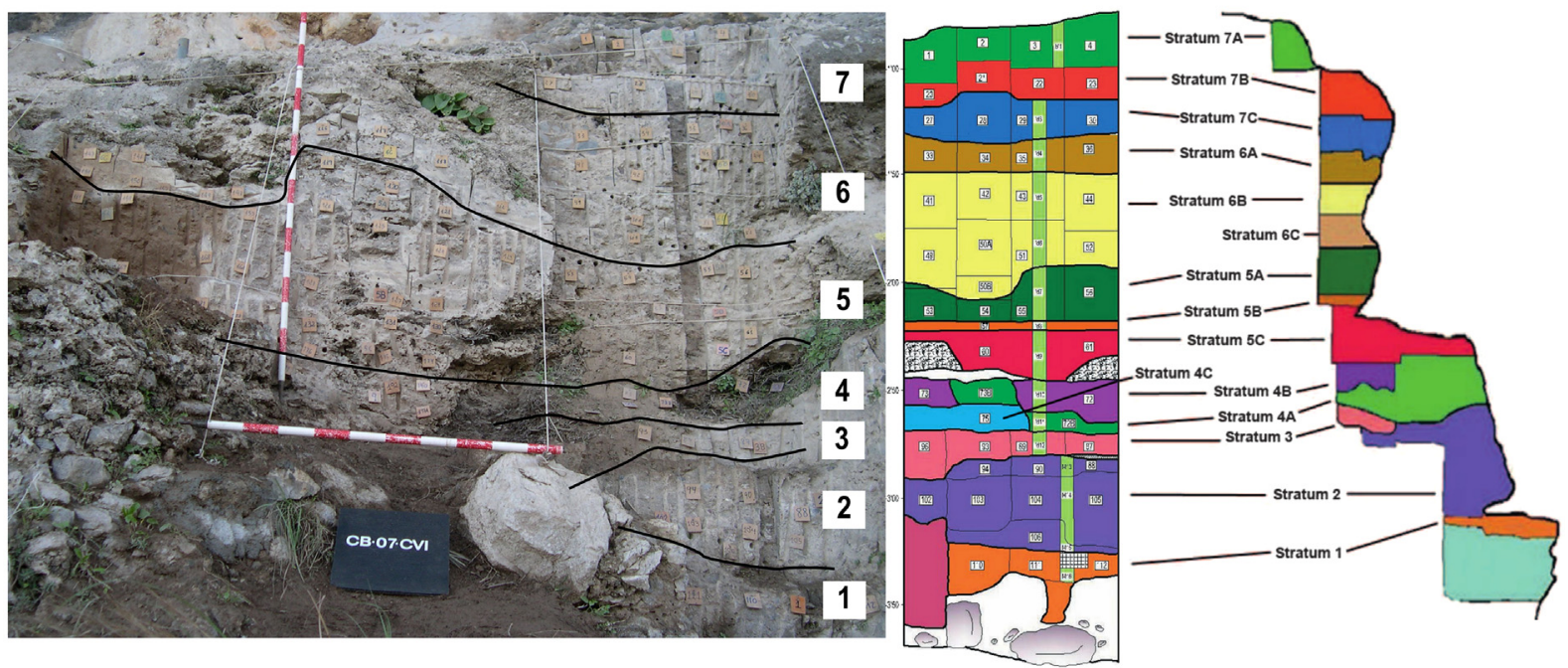

Fig. 3. Section of the rock shelter of Benzú.

Abundant land animal remains have been found, including midand small-sized bone fragments. These remains are the product of intense human activity. Specifically, the remains include bone fragments and splinters belonging to mid-sized mammals and a considerable number of fragments identified as the humeral diaphysis of mid-sized ungulates, intentionally fractured and burnt. Remains corresponding to bovine mammals and other herbivores have also been found (Monclova et al., 2013).

Regarding raw materials for the manufacture of stone tools (over 36,000 industrial remains have been identified to date), silica-rich types of stone were clearly predominant. Among these, we can distinguish between Tertiary silicate-rich compact sandstones (of different colours); red, purplish and greenish radiolarites; homogeneous, black-speckled, yellowish flints; and homogenous or oolitic white flints (Domínguez-Bella et al., 2013). Other lithologies have been attested, but in insignificant proportions.

The result of several archaeological surveys carried out in the region has revealed that most of these raw materials are local in origin. Jurassic radiolarites originate on the NE face of Jebel Musa, but are eroded away as far as the beaches on Bay of Ballenera, near the modern village of Benyounes. The Tertiary local sandstones, which present different colours and grain size, are to this day easy to find in the central area of the bay. Homogenous and oolitic flints are sourced somewhat farther away, but still within the region. They are found in Jurassic calcareous and dolomitic rocky outcrops rich in workable cores (Domínguez-Bella et al., 2013).

Mode III-Mousterian is the predominant lithic technology. The Levallois technique is especially abundant, and centripetal cores are especially common among BN1G. Internal chips are numerous, as are those associated with the beginning of the knapping process and the Levallois technique. The retouched tools (BN2G) include racloirs and points, and the use of notches and denticulate edges is frequent (Ramos et al., 2014 b; 2014a).

Functional analysis (Semenov, 1964) applied to a sample representing the whole sequence (Clemente, 2013) points towards a variety of productive activities related to the exploitation of animal and vegetal resources. The use of hafted tools is attested in stratum 4. The tools manufactured out of local sandstones are particularly well crafted, and have very sharp edges.

\section{Marine resources in the rock shelter of Benzú}

The rock shelter of Benzú is yielding clear evidence of the exploitation of coastal resources, especially molluscs, which are present in all levels (Fig. 4) between strata 7 and 1; ichthyofauna (Fig. 5) are especially abundant in level 5a (Ramos et al., 2011a,b; 2014; Cantillo and Soriguer, 2011; Cantillo, 2012, 2013).

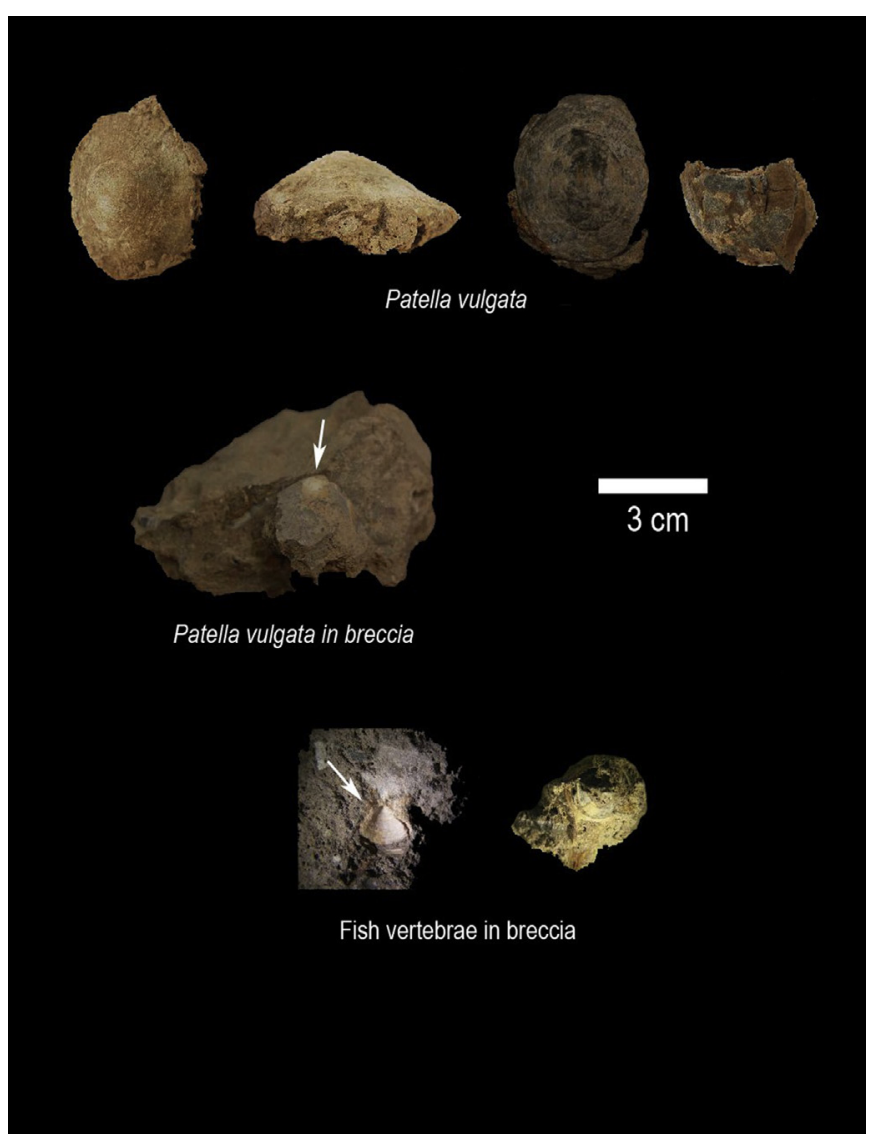

Fig. 4. Patella vulgata and fish vertebrate. Stratum 5. Benzú. 


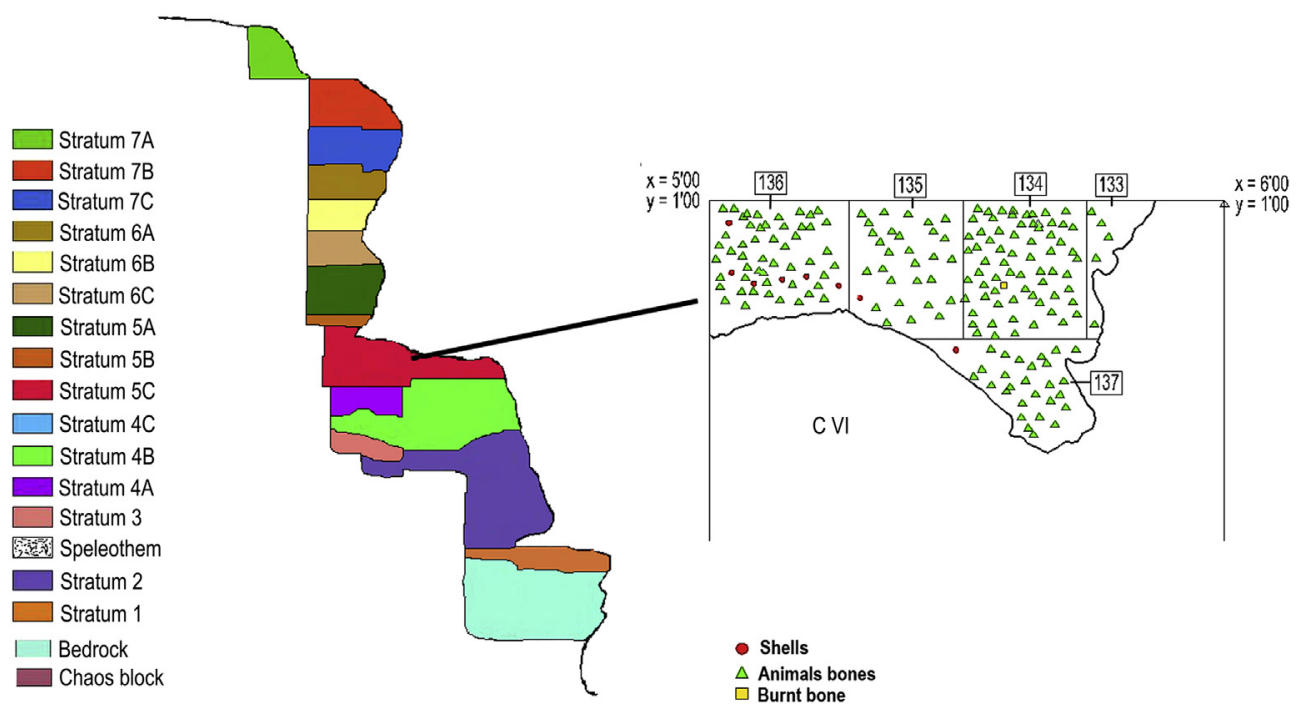

Fig. 5. Plan and section to the position of animals remains (shells and land animals), rock shelter of Benzú.

In order to ensure the comparability of results, we have used the database CLEMAM (Check list of European marine mollusca), published by the Muséum national d'Histoire naturelle (Paris). Taxonomic identification has relied on bibliographic sources (Sabelli, 1982; Lindner, 1983; Poppe and Goto, 1993; Hayward and Ryland, 1996; Hayward et al., 1998; Gofas et al., 2012) and the mollusc collection of the zoology laboratory at the Faculty of Sea Sciences, University of Cádiz. It has not been possible to taxonomically and anatomically identify all specimens with as much precision as could have been wished. In some cases, therefore, identification beyond class has proven unattainable. For quantitative analysis we have used standard biological indices (Moreno Nuño, 1994; Gutiérrez Zugasti, 2009; Cantillo, 2012). Thus, Minimum Number of Individuals (MNI) has been calculated on the basis of Number of Remains (NR).

Concerning molluscs, the vast majority of identified remains (Table 1) correspond to gastropods (99.3\%), and a small proportion to bivalves (0.7\%). Among the gastropods, the patellidae family is clearly predominant in all strata (97.8\%) (Fig. 4), followed far behind by the Siphonariidae (1.5\%) (among which the Siphonaria pectinata is the most common species). The most common patellidae species are Patella vulgata and, in smaller proportions, Patella ferruginea, Patella caerulea, and Siphonaria pectinata. Bivalves are represented by a fragment of Ruditapes decussatus in stratum 6. In absolute terms, the number of samples analysed is not large, as only $10 \%$ of the site has been excavated to date. In consequence, limpets are by far the most common mollusc in Benzú. This was a local species, easy to access and an obvious resource for the inhabitants of the site. These animals adhere to rocks located in the intertidal area, where they form large colonies all year round. They are not greatly exposed to the surf, and are above water for long periods, so their collection is not difficult, and is amenable to their exploitation as a complementary source of nourishment. In addition, they can be collected by recourse to simple tools, such as beach pebbles.

From the taphonomic point of view (Gautier, 1987), the main process observable in the shells of Benzú is cementation, caused by the long exposure of the shells to water permeated soils, provoking the accumulation of calcium carbonate. This factor has impeded to obtain information through functional analysis of the shell edges (Cuenca Solana, 2013). All taxa documented to date were collected for consumption, as shown by the accumulation of discarded shells in specific areas of the site, especially in stratum 5 (areas 135, 136 and 137). The identification of this sector as an area dedicated to food consumption is confirmed by the remains of land animals (bovinae), some of which show traces of exposure to fire (Fig. 5).

Table 1

Taxonomic variability between levels: NISP: Number of Identified Specimens; MNI: Minimum Number of Individuals.

\begin{tabular}{|c|c|c|c|c|c|}
\hline \multirow[t]{2}{*}{ Stratum } & \multirow[t]{2}{*}{ Sediment type } & \multirow[t]{2}{*}{ Date } & \multirow[t]{2}{*}{ Taxon } & \multicolumn{2}{|c|}{ Quantification } \\
\hline & & & & NISP & MNI \\
\hline \multirow[t]{3}{*}{7} & \multirow[t]{3}{*}{ Cemented breccia } & \multirow[t]{3}{*}{$74 \pm 7$ ka. } & Patella caerulea & 2 & 2 \\
\hline & & & Patella vulgata & 2 & 2 \\
\hline & & & Siphonaria pectinata & 1 & 1 \\
\hline \multirow[t]{2}{*}{6} & \multirow[t]{2}{*}{ Micritic lime } & & Patella vulgata & 22 & 9 \\
\hline & & & Ruditapes decussatus & 1 & 1 \\
\hline \multirow[t]{2}{*}{5} & \multirow[t]{2}{*}{ Sands and limes } & \multirow[t]{3}{*}{$168 \pm 11$ ka. } & Patella vulgata & 62 & 28 \\
\hline & & & Siphonaria pectinata & 1 & 1 \\
\hline 4 & Pebbles and limes & & Patella vulgata & 31 & 15 \\
\hline $3 b$ & Speleotheme & $173 \pm 10 \mathrm{ka}$ & - & - & - \\
\hline 3 & Micritic lime & & Patella vulgata & 4 & 2 \\
\hline \multirow[t]{2}{*}{2} & \multirow[t]{2}{*}{ Pebbles and sand } & \multirow[t]{2}{*}{$254 \pm 17 \mathrm{ka}$} & Patella vulgata & 2 & 2 \\
\hline & & & Patella ferruginea & 1 & 1 \\
\hline 1 & \multirow[t]{2}{*}{ Breccia } & & Patella vulgata & 8 & 4 \\
\hline TOTAL & & & & 137 & 68 \\
\hline
\end{tabular}


Alongside these molluscs, the remains of up to seven wellpreserved articulated fish vertebrae were found in level 5a (cemented sands and limes). These remains have been dated with OSL to $168 \pm 11 \mathrm{ka}$.

\section{Evidence in the south of the Iberian Peninsula and the Strait of Gibraltar: Bajondillo and Gibraltar}

Cueva del Bajondillo (Torremolinos, Málaga) is located at a distance of $200 \mathrm{~m}$ from the current coastline and about 15 m.a.s.l. The maximum level pleniglacial coast was - 110/120 m. The $5.4 \mathrm{~m}$ deep stratigraphic sequence includes twenty archaeological strata, spanning the Middle Palaeolithic to the Neolithic. Level Bj19 is fully in character with the Middle Palaeolithic in the south of the Iberian Peninsula (Cortés, ed., 2007). The evidence for the exploitation of marine resources is associated with Mode III technologies practiced by Neanderthals, and has been dated to $150 \mathrm{ka}$. Researchers working on the site have made a coherent case for the parallels between this evidence and that being investigated in South Africa. Nine categories and five species of marine invertebrate have been attested. The most abundant species is the mussel M. galloprovincialis. Two bivalves (Glycymeris sp. and Tracia sp.), the barnacle Balanus trigonus, the snail Stramonita haemastoma, and two further bivalves (Donacilla cornea and Glycymeris panopea) have also been identified. On the basis of the current habitats, the team working at the site believe that these molluscs were collected from the rocks or the beach during tidal ebbs (Cortés, 2007: 2).

Also on the northern shore of the Strait, several caves in Gibraltar have yielded evidence for the presence of some of the last Neanderthal communities in Europe (Finlayson et al., 2006). Carbon, pollen, wood and animal remains (belonging to both land and marine animals) clearly indicate a hunter-gatherer economy which also included the exploitation of marine resources. The most interesting evidence comes from Gorham's Cave. Excavations begun in 1999 have revealed four archaeological levels. We shall focus on the two levels associated with Palaeolithic occupation: Level III, associated with Solutrean technology of the Upper Paleolithic; and Level IV, associated with Mousterian technology of the Middle Palaeolithic. Calibrated radiocarbon dates for hearths found in Level IV point to a chronology around 29-28 ka (Finlayson, 2009). Land animal remains show human-made cuts and other marks which suggest that the animals were butchered prior to their transportation to the cave. The environment in which this community lived has been defined as 'a piece of Africa in Europe' (Finlayson, 2009: 143).

Pollen and animal remain analyses have resulted in the identification of plant and animal species characteristic of sandy plains, wooded areas, swamps, cliffs and coastal areas. Specifically, the specimens identified point towards shifting sand dunes and wooded savannahs inhabited by stone pines, cork oaks and Spanish juniper. Areas of denser vegetation can also be attested at riverside locations (Finlayson et al., 2008); species included willows and reeds; lakes and lagoons were inhabited by ducks and other birds, along with frogs, toads and tortoises. The Spanish ibex, which is also present in the record, lived in the rocky areas around modern Gibraltar (Finlayson, 2009: 147). During cold periods - when the sea was between 80 and $120 \mathrm{~m}$ lower than today, opening a wide land platform, now under water - the ecosystem was similar to that currently found in the relict of Donana, in the south west of the Iberian Peninsula. The shoreline would be nearly $5 \mathrm{~km}$ distant from the cave, and wide beach expanses opened up around modern Gibraltar. The current sea terraces are the remains of stepped paleobeaches (Fa et al., 2000; Rodríguez Vidal and Gracia, 2000; Rodríguez Vidal et al., 2004).
Hunted large species included Sus scrofa, Equus caballus and Bos primigenius (Currant, 2000), and especially Capra pyrenaica and Cervus elaphus. Smaller animals included tortoises, rabbits - the most common - and birds. The remains of Patella and Mytilus, as well as Monachus monachus, Delphinus delphis and fish, clearly attest to the exploitation of the marine environment (Stringer et al., 2008; Brown et al., 2011).

The evidence from Gibraltar has demonstrated the importance of a varied economic strategy for Neanderthal groups, including the exploitation of small land mammals and marine resources, and their advanced technological, cultural and social level (Brown et al., 2011: 266). Cueva de Higueral de Valleja, also in the south of the Iberian Peninsula, near the Guadalete River and approximately $50 \mathrm{~km}$ away from the current coastline (Jennings et al., 2009) has yielded a complete stratigraphic sequence encompassing Mousterian and Upper Palaeolithic technologies. Stratum 5 is associated with Mode III-Mousterian technologies and remains of Pecten maximus, which shows mobility and contact between human groups in the coast and the interior.

\section{Conclusions and synthesis}

The exploitation of marine resources during the Middle and Upper Pleistocene is a current topic of scholarly debate worldwide. In southern Europe, both on the Atlantic and the western and central Mediterranean shores, these economic strategies were carried out by groups of Homo sapiens neanderthalensis. In the Middle East and North Africa (Vanhaeren et al., 2006; Colonese et al., 2011) research has been uneven for various reasons (Marean et al., 2007; McBrearty and Stringer, 2007); in regions such as South Africa, where research has been especially intense, the evidence for these economic strategies is related to groups of Homo sapiens sapiens.

At any rate, the issue is open to multiple approaches involving complex factors, for instance the evolution of the human species and the emergence of social and economic practices which, traditionally, are inflexibly associated with modern humans. The matter, therefore, is but a strand of one of the most important debates about prehistoric society. To date, 'Out of Africa' explanations supported by the 'human revolution' paradigm have had the upper hand in these debates (Mellars and Stringer, 1989; Mellars, 1994; Mellars et al., 2007; Mellars and French, 2011). This idea has been challenged by critical perspectives (McBrearty and Brooks, 2000; McBrearty, 2007) that argue for the gradual emergence of different innovations for a period of over 200,000 years. According to this approach, some modern behavioural patterns, such as diversification of economic strategies, the exploitation of marine resources and the emergence of symbolic thought and artistic manifestations had their origin in the Middle Palaeolithic. There are other approaches, which argue for a more polygenic perspective on technology and behaviour in the Late Middle Pleistocene and the Upper Pleistocene (Conard, 2005).

The dominant model (based on the 'human revolution' paradigm) considers that some factors of progress, for example the exploitation of marine resources and the emergence of symbolic practices - use of ochre, perforated shells, personal adornment were primarily associated with modern humans. The debate has been affected by the alleged dissociation between biology and culture, and as a result Neanderthals have been consistently underrated.

The evidence from southern Europe demonstrates that Neanderthals already had social practices consistent with shellfishing and other forms of exploitation of marine resources which are very similar to those present among modern humans. Furthermore, the record in Higueral de Valleja (Cadiz) and Cueva Antón (Murcia), 
among other sites, confirm mobility and contact between coastal and interior zones (Jennings et al., 2009; Zilhão et al., 2010). In conclusion, economic practices of groups of Neanderthals and of Homo sapiens sapiens in North Africa, as shown by the evidence collected in Taforalt (Bouzouggar et al., 2007; D'Errico et al., 2005) and Ifri n'Ammar (Mikdad et al., 2004; Nami y Moser, 2010) in the eastern Rif (Morocco), were remarkably similar. These practices involved the mobility of human groups between the coast and the interior, as shown by the presence of the remains of marine resources in interior areas.

From our methodological perspective (Arteaga et al., 1998; Ramos, 1999, 2012; Arteaga, 2002), we believe that, despite the usual, biologically-based distinction between two different human groups, hunter-gatherer-fishers on both shores of the Strait of Gibraltar had similar economic practices and lifestyles. This is a momentous debate, as it concerns the very biological conceptualisation of the human race. Shellfishing is increasingly being regarded as a significant activity for the process of evolution. This debate is especially active with regard to East and South Africa, where for different circumstances most of the research has been focused.

The situation is changing. New chronologies and sequences from North Africa, specifically in the region around the Strait of Gibraltar, for example Benzú, confirm that these practices were consistently pursued for over 250,000 years. This chronology predates the earliest instances in South Africa by nearly 70,000 years. Whereas in South Africa these economic practices are associated with Middle Stone Age technologies (McBrearty and Brooks, 2000; Conard, 2005), in Benzú they are related to Mode III-Mousterian technologies. Although little more can be said regarding the specific identity of the practitioners of thesetechnologies, they share economic and technological practices with the inhabitants of Bajondillo or Gibraltar, on the northern shore of the Strait (Finlayson et al., 2006; Cortés, 2007).

The geohistorical region of the Strait of Gibraltar has much more to offer. Benzú and other sites in northern Morocco are guaranteed to have an important impact on the debate.

\section{Acknowledgements}

We wish to thank the Spanish Ministry of Culture (Madrid, Spain) for the permission to carry out the excavation (2006: SGPPH/ LLB/lms73/06), (2007: SGPPH/LLB/Tmc92/7), (2008: SGPPH/ LMS92/07), and the city of Ceuta for funding the project in agreement with the University of Cadiz (Grants numbers provided by the Ciudad Autónoma de Ceuta are: 65.933/20 (01), 47.849/3 (03), 007086, 77.891/3 (09), 96.478/2 (2010), 0-094/2011, 124.111/3 (2011), 23.685/(13)). The excavation also has the support of project HAR2013-43599-P (MINECO). We also wish to thank the reviewers for their useful comments.

Finally, we want to thank all people actively involved in our work in Benzú, especially Manuel Abad, Markus Bastir, David Calado, Simón Chamorro, David Cuenca, Ángel García, María José Gil, Antonio Monclova, Manuela Pérez, José Antonio Riquelme, Joaquín Rodríguez Vidal, Antonio Rosas, Blanca Ruiz Zapata, Antonio Sánchez Marco, Jesús Toledo, Paloma Uzquiano and Débora Zurro.

\section{References}

Abad, M., Rodríguez-Vidal, J., Aboumaria, K., Zaghloul, M.N., Cáceres, L.M., Ruiz, F. Martínez-Aguirre, A., Izquierdo, T., Chamorro, S., 2013. Evidence of MIS 5 sealevel highstands in Gebel Mousa coast (Strait of Gibraltar, North of Africa) Geomorphology 182, 133-146.

Abad, M., Rodríguez-Vidal, J., Ruiz, F., López-González, N., Chamorro, S., Bernal, D. Ramos, J., 2007. Rasgos morfológicos y bioerosivos en un alto nivel marino del Pleistoceno Medio: El Abrigo arqueológico de la Cabililla de Benzú (Ceuta). In:
Lario, J., Silva, P.G. (Eds.), XII Reunión Nacional de Cuaternario. AEQUA, Ávila, pp. 69-70.

Arteaga, O., 2002. Las teorías explicativas de los 'cambios culturales' durante la Prehistoria en Andalucía: Nuevas alternativas de investigación. In: III Congreso de Historia de Andalucía, Córdoba, pp. 247-311.

Arteaga, O., Ramos, J., Roos, A.M., 1998. La Peña de la Grieta (Porcuna, Jaén). Una nueva visión de los cazadores-recolectores del mediodía atlántico-mediterráneo desde la perspectiva de sus modos de vida y de trabajo en la Cuenca del Guadalquivir. In: Sanchidrián, J.L., Simón, M.D. (Eds.), Las culturas del Pleistoceno Superior en Andalucía. Patronato de la Cueva de Nerja, Málaga, pp. 75-109.

Bailey, G.N., Flemming, N.C., 2008. Archaeology of the continental shelf: marine resources, submerged landscapes and underwater archaeology. Quaternary Science Reviews 27, 175-204.

Barker, G., Antoniadou, A., Barton, H., Brooks, I., Candy, I., Drake, N., Farr, L., Hunt, C., Ibrahim, A.A., Inglis, R., Jones, S., Morales, J., Morley, I., Mutri, G., Rabett, R., Reynolds, T., Simpson, D., Twatu, M., White, K., 2009. The cyrenaican prehistory project 2009: the third season of investigations of the Haua Fteah cave and its landscape, and further results from the 2007-2008 fieldwork. Libyan Studies 40, 1-41.

Bar-Yosef Mayer, D.E., 2005. The exploitation of shells as beads in the Paleolithic and Neolithic of the Levant. Paléorient 31 (1), 176-185.

Barrière, J., 1969. Les coquilles marines découvertes sur le sol de la cabane acheuléenne du Lazaret. In: De Lumley, H. (Ed.), Une cabane acheuléenne dans la grotte du Lazaret (Nice), Mémoire de la Société Préhistorique de France 7, pp. 117-118. Paris.

Bate, L.F., 1982. El modo de producción cazador-recolector o la economía del salvajismo. Boletín de Antropología Americana 13, 5-31.

Bicho, N., 2001. The middle Paleolithic occupation of southern Portugal. In: Conard, N.J. (Ed.), Settlement Dynamics of the middle Palaeolithic and middle Stone Age. Kerns Verlag, Tübingen, pp. 513-531.

Bicho, N., Cardoso, J.L., 2010. Paleolithic occupations and lithic assemblages from Furninha cave, Peniche (Portugal). Zephyrus LXVI, 17-38.

Bouzouggar, A., Barton, N., Vanhaeren, M., D'Errico, F., Collcutt, S., Higham, T., Hodge, E., Parfitt, S., Rhodes, E., Schwenniger, J.L., Stringer, C., Turner, E., Ward, S., Moutmir, A., Stambouli, A., 2007. 82,000-year-old shell beads from North Africa and implications for the origins of modern human behavior. Proceedings, National Academy of Sciences 104 (24), 9964-9969.

Brown, K., Fa, D.A., Finlayson, G., Finlayson, C., 2011. Small game and marine resource exploitation by Neanderthals: the evidence from Gibraltar. In: Bicho, N., Haws, J.A., Davis, L.G. (Eds.), Trekking the Shore: Changing Coastlines and the Antiquity of Coastal Settlement. Interdisciplinary Contributions to Archaeology. Springer Science, pp. 247-272.

Cantillo, J.J., 2012. Análisis arqueomalacológico del Abrigo y Cueva de Benzú (Ceuta). El aprovechamiento de los recursos acuáticos por sociedades prehistóricas en la región histórica del Estrecho de Gibraltar. Tesis Doctoral inédita. Universidad de Cádiz.

Cantillo, J.J., 2013. La fauna marina. In: Ramos, J., Bernal, D., Vijande, E., Cantillo, J.J. (Eds.), El Abrigo y la Cueva de Benzú. Memoria de los trabajos arqueológicos de una década en Ceuta (2002-2012). Ciudad Autónoma de Ceuta y Universidad de Cádiz, Cádiz, pp. 299-315.

Cantillo, J.J., Ramos, J., Soriguer, M., Pérez, M., Vijande, E., Bernal, D., DomínguezBella, S., Zabala, C., Hernando, J., Clemente, I., 2010. La explotación de los recursos marinos por sociedades cazadoras-recolectoras-mariscadores y tribales comunitarias en la región histórica del Estrecho de Gibraltar. Férvedes 6, 105-113.

Cantillo, J.J., Soriguer, M., 2011. La explotación de los recursos marinos por las sociedades cazadoras-recolectoras-pescadoras. In: Ramos, J., Bernal, D. Cabral, A., Vijande, E., Cantillo, J.J. (Eds.), Benzú y los orígenes de Ceuta. Ciudad Autónoma de Ceuta. Museo de la Basílica Tardorromana y Universidad de Cádiz, Cádiz, pp. 103-110.

Callapez, P., 2000. Upper Pleistocene marine invertebrates from Gruta da Figueira Brava (Arrábida, Portugal). In: Antunes, M.T. (Ed.), Last Neanderthals in Portugal. Odontologic and other evidence. Memórias da Academia de Ciências de Lisboa, 38. Classe de Ciências, Lisboa, pp. 83-103.

Castañeda, V., 2008. Las primeras ocupaciones humanas de Los Barrios (Cádiz). In: El ejemplo proporcionado por el Río Palmones. Servicio de Publicaciones Universidad de Cádiz, Monografías Historia y Arte, Universidad de Cádiz y Ayuntamiento de Los Barrios, Cádiz.

Chamorro, S., Domínguez-Bella, S., Abad, M., Rodríguez-Vidal, J., 2011. El medio natural durante la formación del yacimiento arqueológico del Abrigo y la Cueva de Benzú. In: Ramos, J., Bernal, D., Cabral, A., Vijande, E., Cantillo, J.J. (Eds.), Benzú y los orígenes de Ceuta, Ciudad Autónoma de Ceuta. Museo de la Basílica Tardorromana de Ceuta y Universidad de Cádiz, Ceuta, pp. 17-42.

Clemente, I., 2013. Análisis funcional de los restos líticos del Abrigo de Benzú a lo largo de 180.000 años de ocupación: una aproximación a las actividades productivas a partir de un sondeo secuencial. In: Ramos, J., Bernal, D., Vijande, E., Cantillo, J.J. (Eds.), El Abrigo y la Cueva de Benzú. Memoria de los trabajos arqueológicos de una década en Ceuta (2002-2012). Ciudad Autónoma de Ceuta y Universidad de Cádiz, Cádiz, pp. 299-315.

Clottes, J., 2001. La Grotte Chauvet. L'art des origines. Collection Arts rupestres. Editions du Seuil, Paris.

Collina-Girard, Bouzouggar, A., 2013. La longue préhistoire des brassages culturels en Méditerranée. In: Hassani-Idrissi (Ed.), Méditerranée. Une histoire à partager. Bayard, Montrouge, pp. 29-57. 
Colonese, A.C., Mannino, M.A., Bar-Yosef Mayer, D.E., Fa, D.A., Finlayson, J.C., Lubell, D., Stiner, M.C., 2011. Marine mollusc exploitation in Mediterranean prehistory: an overview. Quaternary International 239, 86-103.

Conard, N., 2005. An overview of the patterns of behavioural change in Africa and Eurasia during the Middle and late Pleistocene. In: D'Errico, F., Blackwell, L. (Eds.), From Tools to Symbols: from Early Hominids to Moderns Humans. Witwatersrand University Press, Johanesbourg, pp. 294-332.

Cortés, M. (Ed.), 2007. Cueva del Bajondillo (Torremolinos). Secuencia cronocultural y paleoambiental del Cuaternario reciente en la Bahía de Málaga. Servicio de Publicaciones, Centro de Ediciones de la Diputación de Málaga, Málaga.

Cortés, M., Morales, A., Simón, M.D., Lozano, M.C., Vera, J.L., Finlayson, C., RodríguezVidal, J., Delgado, F., Jiménez, F.J., Martínez, F., Martinez-Aguirre, A., Pascual, A., Bergadá, M., Gibaja, J.F., Riquelme, J.A., López, A., Rodrigo, M., Sskai, S., Sugosaki, S., Finlayson, G., Fa, D., Bicho, N., 2011. Earliest known use of marine resources by Neanderthals. PlosOne 6 (9), e24026, 1-15.

Cortés, M., Simón, M.D., 2000. Bahía de Málaga: algunos aspectos fisiográficos y su incidencia sobre los yacimientos arqueológicos pleistocenos en medios kársticos de su ámbito de influencia. I Congreso Andaluz de Espeleología, pp. 217-224. FAE, Ronda.

Cuenca Solana, D., 2013. Utilización de instrumentos de concha para la realización de actividades productivas en las formaciones económico-sociales de los cazadores-recolectores-pescadores y primeras sociedades tribales de la fachada atlántica europea. Publican. Servicio de Publicaciones de la Universidad de Cantabria, Santander. Serie Tesis Doctorales 4.

Currant, A.P., 2000. A review of the quaternary mammals of Gibraltar. In: Stringer, C., Barton, R.N., Finlayson, C. (Eds.), Neanderthals on the Edge: 150th Anniversary Conference of the Forbe's Quarry Discovery, Gibraltar. Oxbow, Oxford, pp. 201-206.

D'Errico, F., Henshilwood, C., Vanhaeren, M., Van Niekerk, K., 2005. Nassarius kraussianus shell beads from Blombos cave: evidence for symbolic behaviour in the Middle Stone Age. Journal of Human Evolution 48, 3-24.

D'Errico, F., Vanhaeren, M., Barton, N., Bouzouggar, A., Mienis, H., Richter, D., Hublin, J.J., McPerron, S., Lozouet, P., 2009. Additional evidence on the use of personal ornaments in the Middle Paleolithic of North Africa. Proceedings, National Academy of Sciences 106 (38), 16051-16056.

De Lumley, H., 1966. Les fouilles de Terra Amata à Nice. Premiers résultats. Bulletin du Musée d'Anthropologie et Préhistoire de Monaco 13, 29-51.

Dennell, R., 1987. Prehistoria económica de Europa. Crítica, Barcelona.

Domínguez-Bella, S., Ramos, J., Barrena, A., Cabral, A., Moreno, A., 2013. Materias primas minerales de los productos tallados. In: Ramos, J., Bernal, D., Vijande, E.Y., Cantillo, J.J. (Eds.), El Abrigo y la Cueva de Benzú. Memoria de los trabajos arqueológicos de una década en Ceuta (2002-2012). Ciudad Autónoma de Ceuta y Universidad de Cádiz, Cádiz, pp. 316-338.

Domínguez-Bella, S., Ramos, J., Bernal, D., Vijande, E., Cantillo, J.J., Cabral, A., Pérez, M., Barrena, A., 2012. Methodological approximation to the archaeological excavation in breccia: the Benzú rock-shelter case (Ceuta, Spain). Antiquity 86, 1167-1178.

Domínguez-Bella, S., Ramos, J., Gracia, J., Morata, D., Castañeda, V., Pérez, M., Montañés, M., Martínez, C., Lazarich, M., Herrero, N., Blanes, C., Reina, A., Arroquia, M.I., Pérez, L.Y., Gómez, M.I., 1995. Estudio geológico, análisis petrológico y aproximación tecnológica del asentamiento del Paleolítico Superior Final del río Palmones (Algeciras, Cádiz). In: Aleixandre, T., Pérez, A. (Eds.), IX Reunión Nacional sobre Cuaternario. Monografías 3, Centro de Ciencias Medioambientales. CSIC, Madrid, pp. 423-436.

Eiwanger, J., 2004. Ex occidente lux-Prähistorische Forschungen im Schatten der Sáulen des Herakles (Marokko). Expeditionen in vergessene Welten. 25 Jahre Archäologische Forschungen in Afrika, Amerika und Asien. AVA Forschungen Band 10. Linden Soft, Aachem, pp. 79-102.

Erlandson, J.M., 2001. The archaeology of aquatic adaptations: paradigms for a new millennium. Journal of Archaeological Research 9, 287-350.

Estévez, J., Vila, A., Terradas, X., Piqué, R., Taulé, M., Gibaja, J.Y., Ruiz, G., 1998. Cazar o no cazar, ies ésta la cuestión? Boletín de Antropología Americana 33, 5-24.

Fa, D.A., 2008. Effects of tidal amplitude on intertidal resource availability and dispersal pressure in prehistoric human coastal populations: the Mediterranean-Atlantic transition. Quaternary Science Reviews 27, 2194-2209.

Fa, D.A., Lario, J., Smith, P., Finlayson, C., 2000. Elementos sumergidos kársticos alrededor de la costa de Gibraltar y su potencial uso por humanos en la Prehistoria. I Congreso Andaluz de Espeleología, pp. 143-149. FAE, Ronda.

Finlayson, C., 2008. On the importance of coastal areas in the survival of Neanderthal populations during the Late Pleistocene. Quaternary Science Reviews 27, 2246-2252.

Finlayson, C., 2009. The Humans Who Went Extinct. Why Neanderthals Died Out and We Survived. Oxford University Press, Oxford.

Finlayson, G., Finlayson, C., Giles, F., Rodríguez-Vidal, J., Carrión, J.S., Recio, J.M., 2008. Cave as archives of ecological and climatic changes in the Pleistocene-The case of Gorham's cave, Gibraltar. Quaternary International 81, 55-63.

Finlayson, C., Giles, F., Rodríguez-Vidal, J., Fa, D., Gutiérrez, J.M., Santiago, A., Finlayson, G., Allué, E., Baena, J., Cáceres, I., Carrión, J.S., Fernández-Jalvo, Y., Gleed-Owen, C.P., Jiménez-Espejo, F.J., López, P., López Sáez, J.A., Riquelme, J.A., Sánchez Marco, A., Giles Guzmán, F., Brown, K., Fuentes, N., Valarino, C.A., Villalpando, A., Stringer, C., Martínez-Ruiz, F., Sakamoto, T., 2006. Late survival of Neanderthals at the southernmost extreme of Europe. Nature 443, 850-853.

Flemming, N.D., Bailey, G.N., Courtillot, V., King, G., Lambeck, K., Ryerson, F., VitaFinzi, C., 2003. Coastal and marine palaeo-environments and human dispersal points across the Africa-Eurasia boundary. In: Brebbia, C.A., Gambin, T. (Eds.),
The Maritime and Underwater Heritage. Wessex Institut of Technology Press, Southampton, pp. 67-74.

Gamble, C., 1999. The Palaeolithic Societies of Europe. Cambridge University Press, Cambridge.

Gautier, A., 1987. Taphonomy groups: how and why? Archaeozoologia 1 (2), 47-52.

Geneste, J.M., 2005. Recherches pluridisciplinaires dans la Grotte Chauvet, 6. Societé Préhistorique Française, Travaux, Paris.

Gofas, S., Moreno, D., Salas, C., 2012. Guía de moluscos marinos de Andalucía Consejería de Medio Ambiente, Junta de Andalucía, Sevilla.

Gracia, F.J., 1999. El litoral gaditano. In: Durán, J.J., Nuche, R. (Eds.), Patrimonio geológico de Andalucía. Enresa, Madrid, pp. 88-95.

Gracia, F.J., 2008. Geomorfología y estratigrafía del Pleistoceno y Holoceno en la banda atlántica de Cádiz. In: Ramos, J. (Ed.), Memoria del proyecto de investigación: La ocupación prehistórica de la campiña litoral y banda atlántica de Cádiz. Arqueología Monografías, Junta de Andalucía, Sevilla, pp. 53-68.

Gutiérrez Zugasti, I., 2009. La explotación de moluscos y otros recursos litorales en la región cantábrica durante el Pleistoceno Final y Holoceno Inicial. Ediciones de la Universidad de Cantabria, Santander.

Hayward, P., Nelson-Smith, T., Shields, C.H., 1998. Flora y fauna de las costas de España y de Europa. Ediciones Omega, Barcelona.

Hayward, P., Ryland, J.S., 1996. Handbooks of the Marine Fauna of North-west Europe. Oxford University Press, Oxford.

Henshilwood, C.S., D'Errico, F., Marean, C.W., Milo, R.G., Yates, R., 2001. An early bone tool industry from the Middle Stone Age at Blombos Cave, South Africa: implications for the origins of modern human behaviour, symbolism and language. Journal of Human Evolution 41, 631-678.

Henshilwood, C.S., D'Errico, F., Yates, F., Jacobs, Z., Tribolo, C., Duller, G.A., Mercier, N., Sealy, J.C., Valladas, H., Watts, I., Wintle, A.G., 2002. Emergence of modern human behaviour: Middle Stone Age engraving from South Africa. Science 295, 1278-1280.

Henshilwood, C.S., D'Errico, F., Vani Nieken, K.L., Conquinot, Y., Jacobs, Z. Lauritzen, S.E., Meno, M., García Monero, R., 2011. A 100.000 year old ochreprocessing workshop at Blombos cave, South Africa. Science 334, 219-222.

Hiscock, P., 1996. Transformations of upper Palaeolithic implements in the Dabba industry from Haua Fteah (Libya). Antiquity 70, 657-664.

Ingold, T., Riches, D., Woodburn, J. (Eds.), 1988. Hunters and Gatherers. Berg, Explorations in Anthropology Series (New York).

Jacobs, Z., Roberts, R., Galbraith, R.F., Deacon, H.J., Grün, R., Mackay, A., Mitchell, P., Vogelsang, R., Wadley, L., 2008. Ages for the Middle Stone Age of sourthern Africa: implications for human behaviour and dispersal. Science 322, 733-735.

Jennings, R.P., Giles, F., Barteon, R.N.E., Collcutt, S.N., Gale, R., Gleed-Owen, C.P., Gutiérrez, J.M., Higham, T.F.G., Parker, A., Price, C., Rhodes, E., Santiago, A., Schweninger, J.L., Turner, E., 2009. New dates and palaeoenvironmental evidence for the Middle to Upper Palaeolithic occupation of Higueral de Valleja Cave, southern Spain. Quaternary Science Reviews 28, 830-839.

Jerardino, A., Marean, C.W., 2010. Shellfish gathering, marine paleoecology and modern human behavior: perspectives from cave PP13B, Pinnacle Point, South Africa. Journal of Human Evolution 59, 412-424.

Jerardino, A., Navarro, R.A., Galimberti, M., 2014. Changing collecting strategies of the clam Donax serra Röding (Bivalvia: Donacidae) during the pleistocene at Pinnacle Point, South Africa. Journal of Human Evolution 68, 58-67.

Klein, R., 2008. Out of Africa and the evolution of human behaviour. Evolutionary Anthropology 17, 267-281.

Kuhn, S.L., Stiner, M.C., Reese, D.S., Güleç, E., 2001. Ornaments of the earliest upper Paleolithic: new insights from the Levant. Proceedings, National Academy of Sciences 98 (13), 7641-7646.

Lee, R.B., 1968. What hunters do for a living, or, how a make out on scarce resources. In: Lee, R.B., De Vore, I. (Eds.), Man the Hunter. The First Intensive Survey of a Single, Crucial Stage of Human Development. Man's Once Universal Hunting Way of Life. Aldine de Gruyter, New York, pp. 30-48.

Lee, R.B., De Vore, I. (Eds.), 1968. Man the Hunter. The First Intensive Survey of a Single, Crucial Stage of Human Development. Man's once Universal Hunting Way of Life. Aldine de Gruyter, New York.

Lindner, G., 1983. Moluscos y caracoles del Atlántico y Mediterráneo. Editorial Omega, Barcelona.

McBrearty, S., 2007. Down with the revolution. In: Mellars, P., Boyle, K., Bar Yosef, O. Stringer, C. (Eds.), Retinking the Human Revolution: New Behavioural and Biological Perspectives on the Origin and Dispersal of Modern Humans. McDonald Institute for Archaeological Research, Cambridge, pp. 133-151.

McBrearty, S., Brooks, A.S., 2000. The revolution that wasn't: a new interpretation of the origin of modern human behaviour. Journal of Human Evolution 39, 453-563.

McBrearty, S., Stringer, C., 2007. The coast in colour. Nature 449, 793-794.

McBurney, C., 1967. The Haua Fteah (Cyrenaica) and the Stone Age in the South-east Mediterranean. Cambridge University Press, Cambridge.

Marean, C., Bar-Matthews, M., Bernatchez, J., Fischer, E., Goldberg, P., Herries, A.I., Jacobs, Z., Jerardino, A., Karkanas, P., Minchillo, T., Nilssen, P., Nilssen, P. Thompson, E., Watts, I., Williams, H., 2007. Early human use of marine resources and pigments in Sout Africa during the Middle Pleistocene. Nature 449, 905-909.

Martin, P.S., Klein, R.G., 1984. Quaternary Extinctions: a Prehistoric Revolution. Tucson University of Arizona Press, Tucson.

Mellars, P., 1994. The upper Palaeolithic revolution. In: Cunliffe, B. (Ed.), Oxford Illustrated Prehistory of Europe. Oxford University Press, Oxford, pp. 42-78. 
Mellars, P., 1999. The Neanderthal problem continued. Current Anthropology 40, $341-350$.

Mellars, P., Boyle, K., Bar-Yosef, O., Stringer, C. (Eds.), 2007. Rethinking the Human Revolution: New Behavioural and Biological Perspectives on the Origin and Dispersal of Modern Humans. McDonald Institute for Archaeological Research, Cambridge.

Mellars, P., French, C., 2011. Tenfold population increase in western Europe at the Neanderthal to modern human transition. Science 333, 623-626.

Mellars, P., Stringer, C. (Eds.), 1989. The Human Revolution: Behavioural and Biological Perspectives in the Origin of Modern Humans. Edinburgh University Press, Edinburgh.

Menanteau, L., Vanney, J.R., Zazo, C., 1983. Belo et son environnement (Détroit de Gibraltar). Étude physique d'un site antique. Casa de Velázquez, Serie Archeologie IV (París)

Mikdad, A., Moser, J., Nami, M., Eiwanger, J., 2004. La stratigraphie du site d'Ifri n'Ammar (Rif Oriental, Maroc): premiers résultats sur les dépots du Paléolithique Moyen. Beitrage zur Allgemeinen und Vergleichenden Archäologie 24, 125-137.

Monclova, A., Toledo, J., Sánchez, P., 2013. El registro de fauna terrestre (mamíferos). In: Ramos, J., Bernal, D. Vijande, E., Cantillo, JJ. (Eds.), El Abrigo y la Cueva de Benzú. Memoria de los trabajos arqueológicos de una década en Ceuta (20022012). Ciudad Autónoma de Ceuta y Universidad de Cádiz, Cádiz, pp. 283-298.

Montes, R., 1989. La grotte 'de los Aviones' Cartagena. Bulletin de la Société Préhistorique Française 86 (2), 40-44.

Moreno Nuño, R., 1994. Análisis arqueomalacológicos en la Península Ibérica. Contribución metodológica y biocultural. Tesis doctoral inédita. Universidad Autónoma de Madrid.

Mourre, V., Villa, P., Henshilwood, C.S., 2010. Early use of pressure flaking on lithic artifacts at Blombos cave, South Africa. Science 330, 659-662.

Nami, M., Moser, J., 2010. La Grotte d'Ifri N'Ammar. Le Paléolithique Moyen. Forschungen zur Archäologie Auseuropäischer Kulturen. Band 9. Reicher Verlag, Wiesbaden.

Otte, M., 1996. Le Paléolithique Inférieur et Moyen en Europe. Armand Colin, Paris.

Otte, M., 2013. Détroits. In: Djinjian, F., Robert, S. (Eds.), Understanding Landscape from Land Discovery to Their Spatial Organization. BAR International Series, Oxford, pp. 67-74.

Poppe, G.T., Goto, Y., 1993. European Seashells. Vol. II (Scaphopoda, Bivalvia, Cephalopoda). Verlag Christa Hemmen, Wiesbaden.

Ramos Fernández, J., Douka, K., Pike, A.W., Thomas, L., Van Calsteren, P., Zilhao, J., 2011-2012. Dating of the Middle to Upper Paleolithic transition at the Abrigo 3 del Humo (Málaga, Spain). Mainake XXXIII, 275-284.

Ramos, J., 1999. Europa Prehistórica. Cazadores Y Recolectores. Sílex, Madrid.

Ramos, J., 2012. El Estrecho de Gibraltar como puente para las sociedades prehistóricas. Editorial La Serranía, Ronda, Málaga.

Ramos, J., 2008. Memoria del proyecto de investigación La ocupación prehistórica de la campiña litoral y banda atlántica de Cádiz. Arqueología Monografías, Junta de Andalucía, Sevilla.

Ramos, J., Bernal, D., Domínguez-Bella, S., Calado, D., Ruiz, B., Gil, M.J., Clemente, I., Durán, J.J., Vijande, E., Chamorro, S., 2008. The Benzu rockshelter: a Middle Palaeolithic site on the North African coast. Quaternary Science Reviews 27, 2210-2218.

Ramos, J., Bernal, D., Cabral, A., Vijande, Cantillo, J.J., 2011a. Benzú y los orígenes de Ceuta. Ciudad Autónoma de Ceuta. Museo de la Basílica Tardorromana y Universidad de Cádiz, Cádiz.

Ramos, J., Bernal, D., Vijande, E., Cantillo, J.J. (Eds.), 2013. El Abrigo y la Cueva de Benzú. Memoria de los trabajos arqueológicos de una década en Ceuta (2002-2012). Ciudad Autónoma de Ceuta y Universidad de Cádiz, Cádiz.

Ramos, J., Bernal, D., Vijande, E., Cantillo, J.J., Barrena, A., Domínguez-Bella, S., Rodríguez Vidal, J., Chamorro, S., Durán, J.J., Abad, M., Calado, D., Ruiz Zapata, B., Gil, M.J., Clemente, I., Uzquiano, P., soriguer, M., Monclova, A., Toledo, J., Almisas, S., 2014a. The Benzu rockshelter (Ceuta). Stratigraphic sequence and record of Hunter Gatherer societies of marine resources with Mode 3 technology in North Africa. In: Sala, R. (Ed.), Pleistocene and Holocene HunterGatherers in Iberia and the Gibraltar Strait: the Current Archaeological Record. Universidad de Burgos, Fundación Atapuerca, pp. 503-505. Burgos.

Ramos, J., Bernal, D., Vijande, E., Cantillo, J.J., Barrena, A., Domínguez-Bella, S., Clemente, I., Rodríguez-Vidal, J., Chamorro, S., Durán, J.J., Abad, M., Calado, D., Ruiz Zapata, B., Gil, M.J., Uzquiano, P., Soriguer, M., Monclova, A., Toledo, J., Almisas, S., 2014b. L'Abri de Benzu (Ceuta). Un site avec une technologie de Mode 3-Paléolithique moyen dans le Nord de l'Afrique. Comptes Rendus Palevol $14,43-61$.

Ramos, J., Cantillo, J.J., 2009. Los recursos litorales en el Pleistoceno y Holoceno. Un balance de su explotación por las sociedades cazadoras-recolectoras, tribales comunitarias y clasistas iniciales en la región histórica del Estrecho de Gibraltar. In: Bernal, D. (Ed.), Arqueología de la Pesca en el Estrecho de Gibraltar. Universidad de Cádiz, Cádiz, pp. 17-80.

Ramos, J., Domínguez-Bella, S., Cantillo, J.J., Soriguer, M., Pérez, M., Hernando, J. Vijande, E., Zabala, C., Clemente, I., Bernal, D., 2011b. Marine resources exploitation by Palaeolithic hunter-fisher-gatherers and Neolithic tribal societies in the historical region of the Strait of Gibraltar. Quaternary International 239, 104-113.

Ramos, J., Herrero, N., Domínguez-Bella, S., Gracia, J., Castañeda, V., 2002. Registro estratigráfico, geomorfología, petrología y tecnología lítica de la ocupación paleolítica del Ringo Rango (Los Barrios, Cádiz). Intento de interpretación sociohistórica. In: Bernal, D., Lorenzo, L. (Eds.), Excavaciones arqueológicas en la villa romana del Puente Grande (Los Altos del Ringo Rango, Los Barrios, Cádiz). Universidad de Cádiz, Cádiz, pp. 39-75.

Rodríguez Vidal, J., Abad, M., Cáceres, L., González-Regalado, M., Lozano, M.C., Ruiz, F., Vera, J.L., Cortéz, M., De La Rubia, J.J., Simón, M.D., 2007. Rasgos morfosedimentarios del piedemonte suroriental de la Sierra de Mijas (Torremolinos, Málaga). In: Cortés, M. (Ed.), Cueva de Bajondillo (Torremolinos). Secuencia cronocultural y paleoambiental del Cuaternario reciente en la Bahía de Málaga. Servicio de Publicaciones. Centro de Ediciones de la Diputación Provincial de Málaga, Málaga, pp. 25-55.

Rodríguez Vidal, J., Cáceres, L.M., Finlayson, J.C., Gracia, F.J., Martínez, A., 2004. Neotectonics and shoreline history of the Rock of Gibraltar, southern Iberia. Quaternary Science Reviews 23 (18-19), 2017-2029.

Rodríguez Vidal, J., Cáceres, L.M., 2005. Niveles escalonados de cuevas marinas cuaternarias en la costa oriental de Gibraltar. Geogaceta 37, 147-150.

Rodríguez Vidal, J., Gracia, J., 2000. Landform analysis and quaternary process of the rock of Gibraltar. In: Finlayson, C., Finlayson, G., Fa, D. (Eds.), Gibraltar during the Quaternary, the Southernmost part of Europe in the Last Two Million Years. Gibraltar Government Heritage, Publications Monographs 1, Gibraltar.

Ruiz Zapata, M.B., Gil, M.J., 2013. Reconstrucción del paisaje vegetal en el contexto del yacimiento de Benzú: Análisis polínico de las cuadrículas BVII y CVII (Campaña del 2007). In: Ramos, J., Bernal, D., Vijande, E., Cantillo, J.J. (Eds.), El Abrigo y la Cueva de Benzú. Memoria de los trabajos arqueológicos de una década en Ceuta (2002-2012). Ciudad Autónoma de Ceuta y Universidad de Cádiz, Cádiz, pp. 267-277.

Sabelli, B., 1982. Guía de moluscos. Editorial Grijalbo, Barcelona.

Shalins, M.D., 1977. La economía de la edad de piedra. Nueva Colección Labor, Barcelona.

Semenov, S., 1964. Prehistoric Technology. Cory. Adams and Mackay, London.

Stiner, M.C., 1994. Honor Among Thieves: a Zooarchaeological Study of Neanderthal Ecology. NJ. Princeton University Press, Princeton.

Stiner, M.C., 2001. Thirty years on the 'broad spectrum revolution' and Palaeolithic demography. Proceedings, National Academy of Sciences 98 (13), 6993-6996.

Stiner, M.C., Munro, N.D., Surovell, T.A., 2000. The tortoise and the hare: small game use, the broad spectrum revolution, and Palaeolithic demography. Current Anthropology 41, 39-74.

Stiner, M.C., Munro, N.D., Surovell, T.A., Tchernov, E., Bar-Yosef, O., 1999. Paleolithic population growth pulses evidenced by small animal exploitation. Science 283, 190-194.

Stringer, C., Finlayson, C., Barton, R., Fernández-Jalvo, Y., Cáceres, I., Sabin, R. Rhodes, E., Currant, A., Rodríguez Vidal, J., Giles, F., Riquelme, J.A., 2008. Neanderthal exploitation of marine mammals in Gibraltar. Proceedings, National Academy of Sciences 105 (38), 14319-14324.

Tavares, C., Soares, J., 1998. Os recursos marinhos nas estratégias de subsistência da Pré-História do Sul de Portugal. Almadan 7, 71-82.

Torres, F., 2008. Aproximación a la geología de la cuenca fluvial del río Palmones. In: Castañeda, V. (Ed.), Las primeras ocupaciones humanas de Los Barrios. El ejemplo proporcionado por el río Palmones. Servicio de Publicaciones Universidad de Cádiz e Ilmo. Ayuntamiento de la Villa de Los Barrios, Cádiz, pp. 67-82.

Vanhaeren, M., D'Errico, F., Stringer, C., James, S.L., Todd, J.A., Milenis, H.K., 2006. Middle Paleolithic shell beads in Israel and Algeria. Science 312, 1785-1788.

Vanney, J.R., Menanteau, L., 2004. Géographie du golfe ibéro-marocain. Instituto Hidrográfico, Casa de Velázquez, Madrid.

Vitagliano, S., 1984. Nota sul Pontiniano Della Grotta dei Moscerini, gaeta (Latina). Atti della XXIV Riunione Scientifica dell'Instituto Italiano di Preistoria e Protostoria nel Lazio 155-164.

Wengler, L., 2001. Settlement during the Middle Paleolithic of the Maghreb. In: Conard, N. (Ed.), Settlement Dynamics of the Middle Paleolithic and Middle Stone Age. Kerns Verlag, Tübingen, pp. 65-89.

Zazo, C., Goy, J.L., Hillaire-Marcel, C., Hoyos, M., Cuerda, J., Ghaleb, B., Bardaji, T., Dabrio, C.J., Lario, J., Silva, P.G., González, A., González, F., Soler, V., 1997. El nivel del mar y los interglaciares cuaternarios: su registro en las costas peninsulares españolas. In: Rodríguez Vidal, J. (Ed.). Cuaternario Ibérico, Sevilla, pp. 23-32.

Zazo, C., Silva, P.G., Goy, J.L., Hillaire-Marcel, C., Ghaleb, B., Lario, J., Bardají, T., González, A., 1999. Coastal uplift in continental collision plate boundaries: data from the Last Interglacial marine terraces of the Gibraltar Strait area (South Spain). Tectonophysics 301, 95-109.

Zilhão, J., 2001. Middle Paleolithic settlement patterns in Portugal. In: Conard, N. (Ed.), Settlement Dynamics of the Middle Paleolithic and Middle Stone Age. Kerns Verlag, Tübingen, pp. 597-608.

Zilhão, J., 2008. Modernos y neandertales en la transición del Paleolítico Medio al Superior en Europa. Espacio, Tiempo y Forma. Serie 1, Nueva época, 1. Prehistoria y Arqueología, pp. 47-58.

Zilhão, J., 2012. Los neandertales del fin del mundo: resultados recientes, In: Turbón, D., Fañanás, L., Rissech, C., Rosa, A. (Eds.), Biodiversidad Humana Y evolución. Universidad de Barcelona, Barcelona, pp. 68-77.

Zilhão, J., Angelucci, D., Badal, E., D'Errico, F., Daniel, F., Dayet, L., Douka, K., Higham, T.F.G., Martínez, M.J., Montes, R., Murcia, S., Pérez, C., Roldán, C., Vanhaeren, M., Villaverde, V., Wood, R., Zapata, J., 2010. Symbolic use of marine shells and mineral pigments by Iberian neandertals. Proceedings, National Academy of Sciences 107, 1023-1028. 